UDC: $547.814+547.455 .623+577.336$

\title{
Fluorescent conjugates of D-glucosamine with 3-thiazolylcoumarins: synthesis, characterization and potential use as cell imaging agents
}

\author{
Ia. B. Kuziv, O. V. Novosylna, I. Ya. Dubey \\ Institute of Molecular Biology and Genetics, NAS of Ukraine \\ 150, Akademika Zabolotnoho Str., Kyiv, Ukraine, 03143 \\ e-mail:dubey@imbg.org.ua
}

\begin{abstract}
Aim. Synthesis and study of glucosamine-coumarin conjugates as possible reagents for the fluorescent cell imaging. Methods. Organic synthesis, NMR, optical spectroscopy, confocal microscopy. Results. D-glucosamine conjugates with 7-substituted 3-thiazolylcoumarins were obtained in 55-82\% yield by the reaction of NHS active esters of carboxy-modified dyes with sugar amino group. The anomeric configuration of the products was elucidated by NMR. Their spectral properties were studied in methanol and phosphate buffer. Preliminary evaluation of possible use of the conjugates for cell staining was performed. Conclusion. Thiazolylcoumarinlabeled glucosamines with bright blue emission are promising reagents for cell imaging.
\end{abstract}

Ke y w ord s: coumarins, glucosamine, conjugates, fluorescence, confocal microscopy

\section{Introduction}

A number of diseases are associated with D-glucose metabolism impairment, e.g. diabetes [1], cancer [2] and some brain diseases [3]. Studies of their mechanisms and medical diagnostics use the conjugates of D-glucose or its analogs with reporter groups. The main application of such reagents is a visualization of glucose uptake and localization in the cells and tissues. Clinical cancer diagnostics commonly uses ${ }^{18} \mathrm{~F}$-FDG (2-fluoro-2-deoxyglucose) in positron emission tomography [4]. ${ }^{13} \mathrm{C}$-labeled glucose was used in magnetic resonance imaging and in the studies of cancer metabolism by chromato-mass spectrometric methods, LC-MS or GC-MS [5]. Some other systems of glucose visualization are free of the isotope labels, but experimentally complicated. 3-Propargyl-D-glucose was proposed as a reagent for imaging the glucose uptake in living cells by stimulated Raman scattering [6]. Bioluminescent imaging based on firefly luciferin/luciferase system employs the luciferase producing tissues and triphenylphosphinemodified luciferin and azide-modified glucosamine, the components of Staudinger ligation [7].

(C) 2020 Ia. B. Kuziv et al.; Published by the Institute of Molecular Biology and Genetics, NAS of Ukraine on behalf of Biopolymers and Cell. This is an Open Access article distributed under the terms of the Creative Commons Attribution License (http://creativecommons.org/licenses/by/4.0/), which permits unrestricted reuse, distribution, and reproduction in any medium, provided the original work is properly cited 
Fluorescence techniques are widely used for the detection and quantification of biological and synthetic compounds in the studies of biomolecular structure and dynamics and medical diagnostics [8, 9]. Carbohydrates labeled with fluorescent dyes are important tools of biomedical research [10]. Fluorescent conjugates of glucose and its analogs have been used e.g. for the studies of glucose transport [11-13], construction of screening systems for drug discovery [14-16], imaging of tumors $[17,18]$ and pancreatic beta and alpha cells [19].

The first fluorescent glucose derivative, 6-(N-(7-nitrobenz-2-oxa-1,3-diazol-4-yl) amino)-6-deoxyglucose, was used to study the glucose transport in red blood cells [11]. Its 2-substituted analog 2-NBDG was prepared to monitor the glucose uptake in E. coli [12] and is now used in standard protocols for the analysis of glucose transport in living cell [13]. Many other dyes were also conjugated with glucose and analogs, including porphyrins [20], cyanines $[15,21,22]$, iridium(III) polypyridine [23], coumarins [19, 24], rhodamines [19, 25, 26], fluorescein [19], dicyanoisophorones [17] and dicyanomethylene-4Hpyranes [18].

Importantly, the conjugation with carbohydrates strongly increases water solubility of lipophilic molecules [27-29].

Glucose and its derivatives get into the cell mainly through GLUTs (Glucose Transporters), membrane proteins facilitating the glucose transport across the cell membrane [30, 31]. Sugar-drug conjugates are extensively used in cell imaging and drug delivery systems based on monosaccharide transport proteins $[10,15$, 16, 31]. Main requirements for the efficient uptake of the conjugates are as small as possible size of the aglycone and the absence of permanently charged groups [26, 32].

We have developed a series of the fluorescent 3-hetarylcoumarins functionalized with carboxyalkyl groups for bioconjugation [3335]. These dyes conform to the requirements for GLUT-mediated uptake. In this work we have prepared their conjugates with D-glucosamine, studied their optical properties and evaluated the suitability for cell imaging.

\section{Materials and Methods}

D-glucosamine hydrochloride, N,N'dicyclohexyl carbodiimide (DCC) and N-hydroxysuccinimide (NHS) were obtained from Acros (Belgium). The solvents were purchased from Macrochim (Ukraine). DMF was dried by distillation over $\mathrm{CaO}$ and $\mathrm{P}_{2} \mathrm{O}_{5}$ and stored over $3 \mathrm{~A}$ molecular sieves. Dioxane was distilled over $\mathrm{KOH}$, triethylamine over ninhydrin and $\mathrm{CaO}$. Methanol for spectroscopy (Labskan, Ireland) was additionally distilled over $\mathrm{KHSO}_{4}$ and $\mathrm{K}_{2} \mathrm{CO}_{3}$. Coumarin derivatives 1-2a,b and 6-7a,b (Scheme 1) were synthesized according to [35], glucosamine conjugate 5 was prepared as described in [24].

Thin layer chromatography was performed on Alugram Xtra Sil G/UV 254 plates (MachereyNagel, Germany) in $\mathrm{CHCl}_{3}-\mathrm{MeOH}$ 8:2.

${ }^{1} \mathrm{H}$ NMR spectra were recorded in DMSO- $d_{6}$ on Varian Gemini-2000 instrument (400 MHz, Varian, USA) using tetramethylsilane as an internal standard; chemical shifts are given in ppm.

Absorption spectra were obtained with UV-2802 spectrophotometer (Unico, USA) in methanol or phosphate buffers. Conjugate concentrations were in the range 4-35 $\mu \mathrm{M}(0.1-1.1$ 
OD units at the main absorption maximum). Working solutions were prepared by adding the aliquots of stock solutions in methanol or DMSO to corresponding solvents.

Fluorescence spectra were recorded on Quanta Master 40 spectrofluorimeter (Photon Technology, Canada) in $1 \times 1 \mathrm{~cm}$ quartz cuvette; sample concentration was in the range (0.5$1.5) \times 10^{-6} \mathrm{M}$. Emission was excited at the absorption maximum and excitation was detected at the emission maximum. Emission spectra of the ionized forms of hydroxycoumarin derivatives in $\mathrm{MeOH}$ were recorded with excitation at a shoulder at 437-440 nm [35]. The fluorescence quantum yields $(\Phi)$ were measured using Coumarin-1 and Coumarin-314 standards (Spectrum Info, Ukraine) as reported in [35].

$\mathrm{pK}_{\mathrm{a}}$ values of the conjugates were determined in titration experiments using the Henderson-Hasselbalch equation [36] as described in [37]. $\mathrm{pH}$-dependent absorption values at $450 \mathrm{~nm}$ were used for $\mathrm{pK}_{\mathrm{a}}$ calculation.

Chromato-mass-spectrometric analysis (LC-MS) was performed in positive and negative mode (APCI ionization) on Agilent 1100LC/MSD SL instrument (Agilent Technologies, USA) equipped with Zorbax SB-C18 Rapid Resolution HT Cartridge $(2.1 \times 30 \mathrm{~mm}, 1.8 \mu \mathrm{m})$ using a $0-100 \%$ gradient $(2 \mathrm{~min})$ of $\mathrm{CH}_{3} \mathrm{CN}$ in $0.1 \%$ formic acid.

\section{General procedure for the synthesis of glucosamine-dye conjugates}

Carboxy-modified dye 1-2a,b $(1.0 \mathrm{mmol})$ and $\mathrm{N}$-hydroxysuccinimide $(1.1 \mathrm{mmol})$ were dissolved in dry amine-free DMF $(400-800 \mu \mathrm{l})$ and DCC $(1.1 \mathrm{mmol})$ was added. In case of $\mathbf{2 a}, \mathbf{b}$, triethylamine $(1.0 \mathrm{mmol})$ was added to increase the acid solubility in DMF. After the overnight activation, D-glucosamine hydrochloride $(1.2 \mathrm{mmol})$ and triethylamine (1.2 mmol) in water were added (final ratio $\mathrm{DMF} / \mathrm{H}_{2} \mathrm{O}$ 4:1). Next day, water (3-5 ml) was added and the mixture was several times extracted with $\mathrm{CHCl}_{3}-\mathrm{EtOH}(9: 1)$. The aqueous suspension was evaporated in vacuum and the residue was crystallized from aqueous dioxane. The precipitate was washed with isopropanol $(2 \times)$ and ether $(2 \times)$ and dried to give yellow crystals.

2-[2-(7-hydroxy-2-oxo-chromen-3-yl)thiazol-4-yl]-N-[(2S,3R,4S, 5S, 6R)-3,4,5-trihydroxy-6-(hydroxymethyl)tetrahydropyran-2-yl] acetamide (3a)

Dioxane-water 1:1 (2 ml). Yield $55 \%$. M.p. $179-181^{\circ} \mathrm{C}$ (dec.). $\mathrm{R}_{\mathrm{f}} 0.25 .{ }^{1} \mathrm{H}$ NMR: $\delta 8.85$ $(1 \mathrm{H}, \mathrm{s}, 4-\mathrm{H}), 8.08-7.92(1 \mathrm{H}, \mathrm{m}, \mathrm{NH}), 7.83(1 \mathrm{H}$, $\mathrm{d}, \mathrm{J}=7.3 \mathrm{~Hz}, 5-\mathrm{H}), 7.51(1 \mathrm{H}, \mathrm{m}, 5-\mathrm{H}$ (thiazole)), $6.88(1 \mathrm{H}, \mathrm{d}, \mathrm{J}=8.3 \mathrm{~Hz}, 6-\mathrm{H}), 6.82(1 \mathrm{H}$, s, 8-H), $6.61(0.2 \mathrm{H}, \mathrm{m}, 1$ '-OH ( $\beta$-anomer $))$, $6.54(0.8 \mathrm{H}, \mathrm{m}, 1$ '-OH ( $\alpha$-anomer $)), 4.99-4.93$ $(1.8 \mathrm{H}, 2 \mathrm{~m}, 1$ ' $-\mathrm{H}$ ( $\alpha$-anomer), 3'-OH or 4'-OH), $4.73\left(1 \mathrm{H}, \mathrm{m}, 3^{\prime}-\mathrm{OH}\right.$ or $\left.4^{\prime}-\mathrm{OH}\right), 4.53-4.45$ $(1.2 \mathrm{H}, 2 \mathrm{~m}, 1$ '- $\mathrm{H}$ ( $\beta$-anomer), 6'-OH), 3.80$3.05\left(\mathrm{H}_{2} \mathrm{O}, \mathrm{CH}_{2}, 3^{\prime}-\mathrm{H}, 4^{\prime}-\mathrm{H}, 5^{\prime}-\mathrm{H}, 6^{\prime}-\mathrm{H}\right)$. LCMS: r.t. $0.857 \mathrm{~min}$ (minor), $0.876 \mathrm{~min}$ (major), isomer ratio $\sim 1: 4 ; \mathrm{m} / \mathrm{z} 465.2[\mathrm{M}+1]^{+}, 463.2$ [M-1]-

4-[2-(7-hydroxy-2-oxo-chromen-3-yl)thiazol-4-yl]-N-[(2S,3R, 4S, 5S, 6R)-3,4,5-trihydroxy-6-(hydroxymethyl)tetrahydropyran-2-yl] butanamide (3b)

Dioxane-water 0.7:1 (1.7 ml). Yield 70\%. M.p. $195-200^{\circ} \mathrm{C}$ (dec.). $\mathrm{R}_{\mathrm{f}} 0.32 .{ }^{1} \mathrm{H}$ NMR: $\delta$ $8.87(1 \mathrm{H}, \mathrm{s}, 4-\mathrm{H}), 7.85(1 \mathrm{H}, \mathrm{d}, \mathrm{J}=8.3 \mathrm{~Hz}$, 
5-H), $7.70(0.1 \mathrm{H}, \mathrm{d}, \mathrm{J}=7.8 \mathrm{~Hz}, \mathrm{NH}), 7.62$ $(0.9 \mathrm{H}, \mathrm{d}, \mathrm{J}=8.3 \mathrm{~Hz}, \mathrm{NH}), 7.41(1 \mathrm{H}, \mathrm{s}, 5-\mathrm{H}$ (thiazole)), $6.87(1 \mathrm{H}, \mathrm{d}, \mathrm{J}=7.3 \mathrm{~Hz}, 6-\mathrm{H}), 6.81$ $(1 \mathrm{H}, \mathrm{s}, 8-\mathrm{H}), 6.50(0.1 \mathrm{H}, \mathrm{m}, 1$ '-OH ( $\beta$-anomer $)$ ), $6.42(0.9 \mathrm{H}, \mathrm{m}, 1$ '-OH ( $\alpha$-anomer $)), 5.01-4.78$ $(1.9 \mathrm{H}, \mathrm{m}, 1$ '- $\mathrm{H}$ ( $\alpha$-anomer), 3 '-OH or 4'-OH), $4.63(1 \mathrm{H}, \mathrm{m}, 3$ ' $-\mathrm{OH}$ or 4 ' $-\mathrm{OH}), 4.56-4.34$ $\left(1.1 \mathrm{H}, \mathrm{m}, 1^{\prime}-\mathrm{H}\right.$ ( $\beta$-anomer $), 6$ '-OH $), 3.70-3.03$ (m, $\left.\mathrm{H}_{2} \mathrm{O}, 3^{\prime}-\mathrm{H}, 4^{\prime}-\mathrm{H}, 5^{\prime}-\mathrm{H}, 6^{\prime}-\mathrm{H}\right), 2.77(2 \mathrm{H}, \mathrm{t}$, $\left.\mathrm{J}=6.3 \mathrm{~Hz}, \mathrm{CH}_{2} \mathrm{CH}_{2} \mathrm{CH}_{2} \mathrm{COO}\right), 2.20(2 \mathrm{H}, \mathrm{t}, \mathrm{J}=$ $6.3 \mathrm{~Hz}, \mathrm{CH}_{2} \mathrm{CH}_{2} \mathrm{CH}_{2} \mathrm{COO}$ ), 1.92 (2H, quint, $\mathrm{J}=6.3 \mathrm{~Hz}, \mathrm{CH}_{2} \mathrm{CH}_{2} \mathrm{CH}_{2} \mathrm{COO}$ ). LC-MS: r.t. $0.928 \mathrm{~min}$ (minor), $0.941 \mathrm{~min}$ (major), isomer ratio $\sim 1: 7 ; \mathrm{m} / \mathrm{z} 493.2[\mathrm{M}+1]^{+}, 491.2[\mathrm{M}-1]^{-}$.

2-[2-(7-methoxy-2-oxo-chromen-3-yl)thiazol-4-yl]-N-[(2S,3R,4S, 5S, 6R)-3,4,5-trihydroxy-6-(hydroxymethyl)tetrahydropyran-2-yl] acetamide (4a)

Dioxane-water 2:1 $(10 \mathrm{ml})$. Yield $66 \%$. M.p. $245-250^{\circ} \mathrm{C}$ (dec.). $\mathrm{R}_{\mathrm{f}} 0.38 .{ }^{1} \mathrm{H}$ NMR $\left(\mathrm{DMSO}-d_{6}\right): \delta 8.91,8.90(1 \mathrm{H}, 2 \mathrm{~s}, 4-\mathrm{H}$, anomers $), 8.04(0.2 \mathrm{H}, \mathrm{d}, \mathrm{J}=8.8 \mathrm{~Hz}, \mathrm{NH}), 8.00$ $(0.8 \mathrm{H}, \mathrm{d}, \mathrm{J}=7.8 \mathrm{~Hz}, \mathrm{NH}), 7.93(1 \mathrm{H}, \mathrm{d}, \mathrm{J}=8.8$ $\mathrm{Hz}, 5-\mathrm{H}), 7.56(0.2 \mathrm{H}, \mathrm{s}, 5-\mathrm{H}$ (thiazole)), 7.54 $(0.8 \mathrm{H}, \mathrm{s}, 5-\mathrm{H}$ (thiazole $)), 7.13(1 \mathrm{H}, \mathrm{m}, 8-\mathrm{H})$, $7.05(1 \mathrm{H}, \mathrm{m}, 6-\mathrm{H}), 6.62(0.2 \mathrm{H}, \mathrm{m}, 1$ ' $-\mathrm{OH}$ ( $\beta$-anomer $)), 6.54\left(0.8 \mathrm{H}, \mathrm{d}, \mathrm{J}=3.4 \mathrm{~Hz}, 1^{\prime}-\mathrm{OH}\right.$ $(\alpha$-anomer $)), \quad 5.10-4.25 \quad\left(4 \mathrm{H}, \mathrm{m}, 1^{\prime}-\mathrm{H}\right.$, ( $\alpha$-anomer), 3'-OH, 4'-OH, 1'-H ( $\beta$-anomer), 6'- $\mathrm{OH}), 3.89\left(3 \mathrm{H}, \mathrm{s}, \mathrm{OCH}_{3}\right), 3.78-3.20(\mathrm{~m}$, 3'- $\mathrm{H}, 4^{\prime}-\mathrm{H}, 5^{\prime}-\mathrm{H}, 6^{\prime}-\mathrm{H}, \mathrm{CH}_{2} \mathrm{COO}, \mathrm{H}_{2} \mathrm{O}$ ), 3.19$3.04\left(1 \mathrm{H}, \mathrm{m}, 2^{\prime}-\mathrm{H}\right) .{ }^{1} \mathrm{H}$ NMR (DMSO- $d_{6}+$ $\left.\mathrm{D}_{2} \mathrm{O}\right): \delta 8.80(1 \mathrm{H}, \mathrm{s}, 4-\mathrm{H}), 8.07(0.2 \mathrm{H}$, br. s, $\mathrm{Hz}, \mathrm{NH}), 7.98(0.8 \mathrm{H}$, br. s, NH), $7.81(1 \mathrm{H}, \mathrm{d}$, $\mathrm{J}=8.8 \mathrm{~Hz}, 5-\mathrm{H}), 7.50(0.2 \mathrm{H}, \mathrm{s}, 5-\mathrm{H}$ (thiazole)), $7.49(0.8 \mathrm{H}, \mathrm{s}, 5-\mathrm{H}$ (thiazole) $), 7.03(1 \mathrm{H}$, br. s, $8-\mathrm{H}), 7.00(1 \mathrm{H}, \mathrm{d}, \mathrm{J}=8.8 \mathrm{~Hz}, 6-\mathrm{H}), 4.97(0.8 \mathrm{H}$, $\mathrm{d}, \mathrm{J}=2.9 \mathrm{~Hz}, 1$ ' $-\mathrm{H},(\alpha$-anomer $)), 4.49(0.2 \mathrm{H}$, $\mathrm{d}, \mathrm{J}=8.8 \mathrm{~Hz}, 1$ '- $\mathrm{H}(\beta$-anomer $)), 3.85(3 \mathrm{H}, \mathrm{s}$, $\left.\mathrm{OCH}_{3}\right), 3.82$ (HOD), 3.74-3.28 (6H, m, 3'- $\mathrm{H}$, 4'- $\mathrm{H}, 5^{\prime}-\mathrm{H}, 6$ ' $\left.-\mathrm{H}, \mathrm{CH}_{2} \mathrm{COO}\right), 3.19-3.04(1 \mathrm{H}$, m, 2'-H). LC-MS: r.t. $0.692 \mathrm{~min}$ (minor), 0.704 min (major), isomer ratio $\sim 1: 8 ; \mathrm{m} / z$ 479.1 $[\mathrm{M}+1]^{+}$.

4-[2-(7-methoxy-2-oxo-chromen-3-yl)thiazol-4-yl]-N-[(2S,3R,4S, 5S, 6R)-3,4,5-trihydroxy-6-(hydroxymethyl)tetrahydropyran-2-yl] butanamide (4b)

Dioxane-water 1:1 $(10 \mathrm{ml})$. Yield $82 \%$. M.p. $219-220^{\circ} \mathrm{C}$ (dec.). $\mathrm{R}_{\mathrm{f}} 0.46 .{ }^{1} \mathrm{H}$ NMR: $\delta$ $8.93(1 \mathrm{H}, \mathrm{s}, 4-\mathrm{H}), 7.96(1 \mathrm{H}, \mathrm{d}, \mathrm{J}=8.8 \mathrm{~Hz}$, 5-H), $7.71(0.2 \mathrm{H}, \mathrm{d}, \mathrm{J}=6.8 \mathrm{~Hz}, \mathrm{NH}), 7.63$ $(0.8 \mathrm{H}, \mathrm{d}, \mathrm{J}=5.8 \mathrm{~Hz}, \mathrm{NH}), 7.44(1 \mathrm{H}, \mathrm{s}, 5-\mathrm{H}$ (thiazole), $7.13(1 \mathrm{H}, \mathrm{s}, 8-\mathrm{H}), 7.05(1 \mathrm{H}, \mathrm{d}, \mathrm{J}=$ $7.3 \mathrm{~Hz}, 6-\mathrm{H}), 6.51 \quad\left(0.2 \mathrm{H}, \mathrm{m}, 1^{\prime}-\mathrm{OH}\right.$ $(\beta$-anomer $), \quad 6.43 \quad\left(0.8 \mathrm{H}, \quad \mathrm{m}, \quad 1^{\prime}-\mathrm{OH}\right.$ $(\alpha$-anomer $)), \quad 5.01-4.80 \quad\left(1.8 \mathrm{H}, \mathrm{m}, 1^{\prime}-\mathrm{H}\right.$ ( $\alpha$-anomer), 3'-OH or 4'-OH), $4.65(1 \mathrm{H}, \mathrm{m}$, 3'- $\mathrm{OH}$ or $\left.4^{\prime}-\mathrm{OH}\right), 4.53\left(0.2 \mathrm{H}, \mathrm{m}, 1^{\prime}-\mathrm{H}\right.$ ( $\beta$-anomer $)), 4.42\left(1 \mathrm{H}, \mathrm{m}, 6{ }^{\prime}-\mathrm{OH}\right), 3.90(3 \mathrm{H}$, s, $\left.\mathrm{OCH}_{3}\right), 3.68-3.44\left(4 \mathrm{H}, \mathrm{m}, 3^{\prime}-\mathrm{H}, 4^{\prime}-\mathrm{H}, 5^{\prime}-\mathrm{H}\right.$, 6'-H), 3.17-3.03 (1H, m, 2'-H), $2.79(2 \mathrm{H}, \mathrm{m}$, $\mathrm{CH}_{2} \mathrm{CH}_{2} \mathrm{CH}_{2} \mathrm{COO}$ ), 2.20 (2H, m, $\left.\mathrm{CH}_{2} \mathrm{COO}\right)$, $1.93\left(2 \mathrm{H}, \mathrm{m}, \mathrm{CH}_{2} \mathrm{CH}_{2} \mathrm{CH}_{2} \mathrm{COO}\right)$. LC-MS: r.t. $0.735 \mathrm{~min}$ (minor), $0.743 \mathrm{~min}$ (major), isomer ratio $\sim 1: 6 ; m / z 507.0[\mathrm{M}+1]^{+}$.

\section{Confocal microscopy}

HeLa cells were cultured on glass cover slips in Dulbecco's modified Eagle's medium (DMEM) supplemented with glucose $(4.5 \mathrm{~g} / \mathrm{L})$, $10 \%$ fetal calf serum, $50 \mathrm{mg} / \mathrm{mL}$ penicillin/ streptomycin at $37^{\circ} \mathrm{C}$ in a humidified atmosphere containing $5 \% \mathrm{CO}_{2}$. The cells were washed with PBS buffer for 3 times, then the medium was replaced with fresh DMEM sup- 
plemented with glucose $(1.0 \mathrm{~g} / \mathrm{L})$ and compound $\mathbf{3 a}, \mathbf{3 b}$ or $\mathbf{5}$ (final concentration $100 \mu \mathrm{M}$ ) for $1.5 \mathrm{~h}$. The cells were quickly washed with PBS $(3 \times)$ and confocal microscopic images were taken immediately with Leica TCS SPE microscope (Leica Microsystems, Germany) equipped with $60 \times$ oil immersion objective. Dyes were excited by $405 \mathrm{~nm}$ laser and the fluorescence was collected in $420-540 \mathrm{~nm}$ region.

\section{Results and Discussion}

Monosaccharide derivatives of organic molecules were studied for over a century [38]. The literature analysis revealed the structural features of the conjugates of glucose and its analogs efficiently transported into the cell via the GLUT-specific mechanism. In most cases, relatively small molecules are conjugated at C-1 or C-2 sugar position; the transport of other positional glucose conjugates was also studied $[6,11,39]$.

The reporter groups are often attached via the linkers, although the data on their effect on cellular uptake are limited $[17,40]$. One- or two-ring heterocycles conjugated directly to glucosamine $[7,11,12,24]$ or its 1-hydroxyl group [18] are transported by GLUTs. The conjugation can be performed via the alkylation of glucose OH-groups $[6,17,18,40]$, S-alkylation of its thioanalogs [25] or $\mathrm{N}$-acylation of amino derivatives $[7,19,26]$.

Taking this into account, we have attached the thiazolylcoumarin dyes to D-glucosamine via the methylene and propylene linkers. Such conjugates would potentially be water-soluble and could be transported in the cell by GLUTs.

Synthesis of the conjugates. 3-Thiazolylcoumarin-labeled glucosamines were obtained via the active ester approach (Scheme 1). The carboxylic groups of starting carboxyalkylmodified dyes 1-2a,b were activated with 1.1. eq. of N,N'-dicyclohexyl carbodiimide (DCC) and N-hydroxysuccinimide (NHS) in dry dimethylformamide. Subsequent selective reaction of NHS active esters with aliphatic amino group of D-glucosamine (20\% molar excess over the activated dye) was carried out in water-DMF mixture (4:1) where both sugar and dyes are soluble.
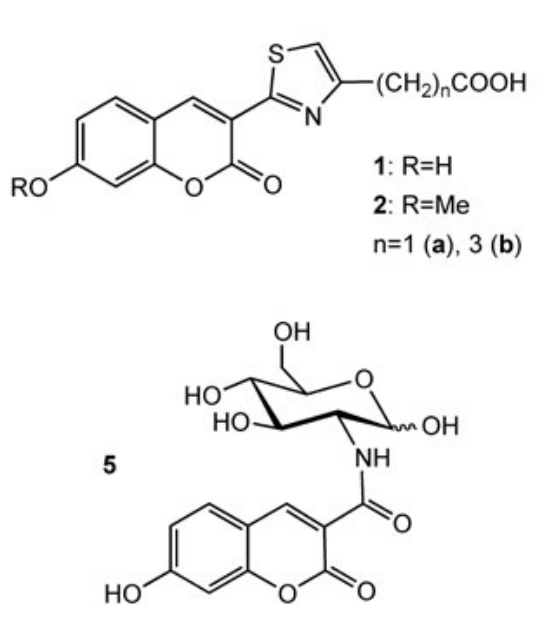
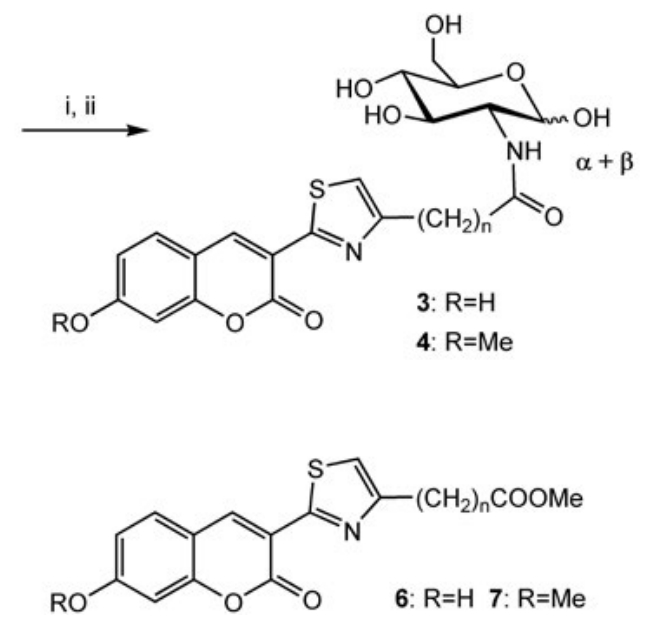

Scheme 1. Synthesis of glucosamine-dye conjugates. (i) DCC, NHS, DMF, r.t.; (ii) D-glucosamine hydrochloride, $\mathrm{Et}_{3} \mathrm{~N}$, aq. DMF, r.t., 55$82 \%$. 5-7 - reference compounds. 
The purification of coupling products was performed by extraction and crystallization. The purity of the conjugates $\mathbf{3 - 4 a , b}$ was above $97 \%$ by LC-MS.

${ }^{1} \mathrm{H}$ NMR and LC-MS data show that all conjugates are the mixtures of two isomers, presumably the diastereomeric mixtures of $\alpha$ - and $\beta$-anomers.

In NMR spectra, some protons $(4-\mathrm{H}, \mathrm{NH}$, 4-H (thiazole), 1'-H, 1'-OH) appear as two separate signals (coumarin 4-H signals are resolved as well, but they are partially overlapped that complicates the integration).

The spectrum of $4 \mathbf{a}$ in DMSO- $d_{6}+\mathrm{D}_{2} \mathrm{O}$ (where the resonances of exchangeable protons are suppressed) allowed for efficient analysis of the anomers. The signals of 1'-H protons are observed as doublets at 4.97 (major isomer) and 4.49 (minor isomer) ppm. They were assigned to $\alpha$ - and $\beta$-anomer, respectively, in accordance with the reported chemical shifts for the anomers of $\mathrm{N}$-acetylglucosamine [41] and coupling constants. The ${ }^{3} \mathbf{J}_{1^{\prime}-2}$, constant of the anomeric proton of sugar derivatives is known to depend on its configuration, and the experimental values of these constants (2.9 and $8.8 \mathrm{~Hz}$ for the doublets at 4.97 and $4.49 \mathrm{ppm}$ ) are typical for $\alpha$ - and $\beta$-anomers of glucopyranosides, respectively [42].

In the spectrum of $\mathbf{4 a}$ in dry DMSO- $d_{6}$, 1 '-H resonance of $\alpha$-anomer appears as a triplet due to the coupling with close constants with 2 ' $-\mathrm{H}(\mathrm{J}=4 \mathrm{~Hz})$ and 1 ' $-\mathrm{OH}(\mathrm{J}=3.5 \mathrm{~Hz})$ protons, whereas the $\beta$-anomeric proton appears as a doublet of doublets.

Similar NMR patterns are observed for other conjugates, with isomer ratio from 1:3 to $1: 9$. In all cases, $\alpha$-anomer is a major component of the mixture. Probably, this anomer can be stabilized by the intramolecular hydrogen bond between 1'-OH and amide carbonyl [41].

In HPLC step of LC-MS analysis each conjugate is eluted as two peaks with small difference in retention times (0.1-0.2 $\mathrm{min})$ and the same molecular weight $(\mathrm{m} / \mathrm{z})$. The ratio of isomers is in the range (1:4)-(1:8). The minor isomer is always a faster running one.

Photophysical characteristics of the conjugates. Spectral-fluorescent properties of compounds were studied in $\mathrm{MeOH}$ and, in case of 7-hydroxyl derivatives, also in phosphate buffers at $\mathrm{pH}$ 4.7-10.0. Compounds 6-7a,b and 5 were taken for comparison.

Noteworthy, 7-methoxy derivatives $\mathbf{4 a , b}$ are not readily soluble in water. The conjugates 3a,b have sufficient water solubility for spectroscopic studies even at $\mathrm{pH} 4.7$ (in contrast to the dyes $\mathbf{1 a}$ and $\mathbf{1 b}$; the lowest $\mathrm{pH}$ where they are still soluble in water is about 6.3). At acidic $\mathrm{pH}, 7-\mathrm{OH}$ group is neutral, whereas in basic solution it is deprotonated [35, 37].

The absorption spectra of all conjugates contain the UV band (257-263 $\mathrm{nm}$ in methanol and acidic buffer, $283 \mathrm{~nm}$ at $\mathrm{pH} \mathrm{10)}$ and much more intense band in visible region (378-383 and $427-428 \mathrm{~nm}$, respectively). The conjugates exhibit bright blue fluorescence with high fluorescence quantum yields $(\Phi)$ and large Stokes shifts (71-73 nm in $\mathrm{MeOH}, 100-102$ $\mathrm{nm}$ at acidic $\mathrm{pH})$.

In general, optical properties of the conjugates are close to those for corresponding free dyes (Table 1).

In methanol the conjugates $4 a$ and $4 b$ have close extinction coefficients with each other and with respective dyes (Table 1). However, the conjugation has different effects on the 
Table 1. Spectral properties of compounds.*

\begin{tabular}{|c|c|c|c|c|c|c|}
\hline Cpd & Solvent & $\begin{array}{c}\lambda_{\max }(\mathrm{UV}), \mathrm{nm} \\
\left(\varepsilon, \times 10^{3} \mathrm{M}^{-1} \mathrm{~cm}^{-1}\right)\end{array}$ & $\begin{array}{c}\lambda_{\max }(\mathrm{Vis}), \mathrm{nm} \\
\left(\varepsilon, \times 10^{3} \mathrm{M}^{-1} \mathrm{~cm}^{-1}\right) \\
\end{array}$ & $\begin{array}{c}\mathrm{Ex}_{\max }, \mathrm{nm} \\
\left(\lambda_{\mathrm{em}}\right)\end{array}$ & $\begin{array}{c}\mathrm{Em}_{\max }, \mathrm{nm} \\
\left(\lambda_{\mathrm{ex}}\right)\end{array}$ & $\Phi$ \\
\hline $3 \mathbf{a}$ & $\mathrm{MeOH}$ & $261(6.7)$ & $383(26.2)$ & $384(455)$ & $\begin{array}{l}456(383) \\
483(440)\end{array}$ & 0.52 \\
\hline $3 \mathbf{b}$ & -"'- & $261(6.9)$ & $383(25.8)$ & $384(455)$ & $\begin{array}{l}457(383) \\
481(440) \\
\end{array}$ & 0.52 \\
\hline $4 a$ & -"- & $258(6.9)$ & $380(26.6)$ & $381(450)$ & $452(379)$ & 0.98 \\
\hline $4 b$ & $-"-$ & $257(6.9)$ & $379(26.3)$ & $382(455)$ & 454 (379) & 0.66 \\
\hline 5 & -"- & $<240 * *$ & $\begin{array}{c}352(21.7) \\
408(4.0) \\
\end{array}$ & $353(405)$ & $\begin{array}{l}405(352) \\
448(407)\end{array}$ & 0.70 \\
\hline $6 \mathbf{6 a}$ & -" & $260(7.0)$ & $382(28.1)$ & $382(450)$ & $\begin{array}{l}454(380) \\
482(437)\end{array}$ & 0.81 \\
\hline $6 b$ & -"'- & $260(7.8)$ & $382(28.0)$ & $382(450)$ & $\begin{array}{l}458(380) \\
482(437) \\
\end{array}$ & 0.85 \\
\hline $7 \mathbf{a}$ & -"'- & $257(7.6)$ & $378(30.5)$ & $380(450)$ & $450(380)$ & 0.81 \\
\hline $7 \mathbf{b}$ & -"'- & $259(7.1)$ & $380(27.1)$ & $380(450)$ & $453(380)$ & 0.80 \\
\hline $3 a$ & $\mathrm{~PB}, \mathrm{pH} 4.7$ & $262(6.5)$ & $378(24.8)$ & $380(480)$ & $480(378)$ & 0.84 \\
\hline $3 \mathbf{b}$ & -"- & $262(6.5)$ & $379(24.0)$ & $382(480)$ & $480(378)$ & 0.78 \\
\hline 5 & -"- & $<240 * *$ & $352(22.2)$ & $355(445)$ & $447(352)$ & 0.80 \\
\hline $3 \mathbf{a}$ & $\mathrm{PB}, \mathrm{pH} 6.4$ & $262(6.36)$ & $380(23.3)$ & $\begin{array}{l}380(440) \\
382(480) \\
\end{array}$ & $\begin{array}{l}481(380) \\
483(440) \\
\end{array}$ & 0.85 \\
\hline $3 \mathbf{b}$ & -"- & $263(6.6)$ & $381(23.2)$ & $\begin{array}{l}382(480) \\
381(440) \\
\end{array}$ & $\begin{array}{l}481(380) \\
484(440) \\
\end{array}$ & 0.78 \\
\hline $3 \mathbf{a}$ & $\mathrm{PB}, \mathrm{pH} 10.0$ & $283(7.1)$ & $428(34.7)$ & 425 (482) & $483(427)$ & 0.57 \\
\hline $3 \mathbf{b}$ & -"- & $283(7.4)$ & $427(34.1)$ & $426(482)$ & $484(427)$ & 0.68 \\
\hline 5 & -"'- & $252(9.1)$ & $404(38.2)$ & $404(445)$ & $447(404)$ & 0.95 \\
\hline
\end{tabular}

* $\lambda_{\max }-$ absorption maximum at UV or visible region; $\mathrm{Ex}_{\max }-$ excitation maximum; $\mathrm{Em}_{\max }-$ emission maximum; $\lambda_{\mathrm{em}}-$ emission wavelength used for recording the excitation spectrum; $\lambda_{\mathrm{ex}}-$ excitation wavelength for the emission spectrum; $\Phi$ - fluorescence quantum yield; PB $-100 \mathrm{mM}$ phosphate buffer; $* * \lambda_{\max }$ and $\varepsilon$ were not accurately measured as the samples contained DMSO from the stock solution of $\mathbf{5}$.

fluorescence quantum yield: it increases in case of $\mathbf{4 a}$ and decreases for $\mathbf{4 b}$ as compared to $7 \mathbf{a}$ and $7 \mathbf{b}$ respectively.

The emission spectra of 7-hydroxyl derivatives $\mathbf{3 a}$ and $\mathbf{3 b}$ are similar in the same solvents being identical to the spectra of corresponding dyes (1a and $\mathbf{1 b}$ in phosphate buffer, 6a and $\mathbf{6} \mathbf{b}$ in $\mathrm{MeOH})$. The quantum yields of $\mathbf{3 a}, \mathbf{b}$ in methanol are substantially lower as compared to non-conjugated $\mathbf{6 a}, \mathbf{b}$ (Table 1).
In acidic buffer UV-Vis, the excitation and emission spectra and extinction coefficients of compounds $\mathbf{3 a}, \mathbf{b}$ are close to those for free dyes [35]. $\Phi$ value of $\mathbf{3 a}$ in acidic medium is somewhat higher than that of $\mathbf{3 b}$. In the basic solution where 7-hydroxycoumarins are ionized the absorption and excitation spectra of the conjugates $\mathbf{3 a}, \mathbf{b}$ and free dyes $\mathbf{1} \mathbf{a}, \mathbf{b}$ are close; the shapes of their emission spectra are identical, but the $\Phi$ value of $\mathbf{3 a}$ is lower than that of $\mathbf{3 b}, \mathbf{1 a}$ and $\mathbf{1 b}$. 
The emission spectra of the phenolate forms of 3a,b in basic buffer (pH 10.0) and in methanol (excitation at $440 \mathrm{~nm} \mathrm{[35])} \mathrm{are} \mathrm{almost}$ identical (Fig. 1, upper). However, there is a substantial difference between the spectra in $\mathrm{MeOH}$ (excited at $383 \mathrm{~nm}$ ) and acidic buffer (pH 4.7). The $\mathrm{Em}_{\max }$ shifted from $454 \mathrm{~nm}$ in $\mathrm{MeOH}$ to $480 \mathrm{~nm}$ in aqueous solution and the spectra have different shapes, despite the absorption and excitation spectra in these solvents are close. The emission profiles of $\mathbf{3 a , b}$ at $\mathrm{pH} 4.7$ look as superpositions of the spectra in $\mathrm{MeOH}$ obtained with excitation at the absorption maximum and at long-wavelength shoulder (430-440 nm). The reason of this effect is the proton transfer from $7-\mathrm{OH}$ to the carbonyl group in the excited state. This phenomenon is typical for 7-hydroxycoumarins $[43,44]$ and is explained by the proton relay move through water molecules [45].

The conjugate $\mathbf{5}$ demonstrates similar features (Fig. 1, lower). Its UV-Vis and excitation spectra in $\mathrm{MeOH}$ and at $\mathrm{pH} 4.7$ are identical below $380 \mathrm{~nm}$ (the band corresponding to the absorption of non-ionized form). The absorption spectrum of 5 in $\mathrm{MeOH}$ contains an additional band at $408 \mathrm{~nm}$ (absent in acidic medium) corresponding to some amount of the ionized form still present in methanol. The emission spectra in methanol and acidic buffer significantly differ whereas the spectra in acidic and basic aqueous solutions are similar. The spectrum at acidic $\mathrm{pH}$ contains a low intensity shoulder at 390$410 \mathrm{~nm}$. This is possibly the emission of the excited state of 5 with non-ionized 7-OH group, which differs from the emission of the ionized species, but is close to the emission of nonionized form in $\mathrm{MeOH}$. Its low intensity may be due to the proton transfer in the excited state. $p K_{\mathrm{a}}$ determination. $\mathrm{pH}$ dependence of the absorption and fluorescence spectra is a common feature of ionizable 7-hydroxycoumarins $[35,43,44]$. We have used a classical Henderson-Hasselbalch approach [36] to determine the $\mathrm{pK}_{\mathrm{a}}$ values of two glucosamine conjugates. Their absorption spectra were recorded in a series of phosphate buffers of varying $\mathrm{pH}$ (Fig. 2). $\mathrm{pK}_{\mathrm{a}}$ constants of the conjugates were then obtained from the $\mathrm{pH}$-dependent absorption changes at $450 \mathrm{~nm}$.

The $\mathrm{pK}_{\mathrm{a}}$ values of the conjugates $\mathbf{3 a}$ and $\mathbf{3 b}$ are almost identical (7.28 and 7.32 , respectively), as well as their isosbestic points (313 and $394 \mathrm{~nm}) . \mathrm{pK}_{\mathrm{a}}$ values are close to those previously measured for $\mathrm{N}^{4}$-cytidine conjugates with dyes $\mathbf{1 a}$ and $\mathbf{1 b}$ [37].

Cell imaging. As the conjugates meet the requirements for cell imaging agents, it was natural to study their uptake and distribution in the cell. We were also interested in the fact that the reagent $\mathbf{5}$ did not stain the cells, in contrast to its analog containing the fluorinesubstituted 7-hydroxycuomarin [24]. We have thus performed the preliminary staining experiments with reagents $\mathbf{3 a}, \mathbf{3 b}$ and $\mathbf{5}$.

The typical experiments on GLUT-mediated uptake include: incubation of the cells in a medium with zero or low glucose content [46] (rarely used step); incubation with the test compounds at various glucose concentrations; washing followed by confocal microscopy. Sometimes the cells are fixed with formaldehyde at the last step.

We have carried out the tests in a culture of HeLa cells with low (1.0 g/L) glucose concentration (Fig. 3). The cells were not fixed as this significantly reduced the signal. The images were obtained after a quick washing since the 

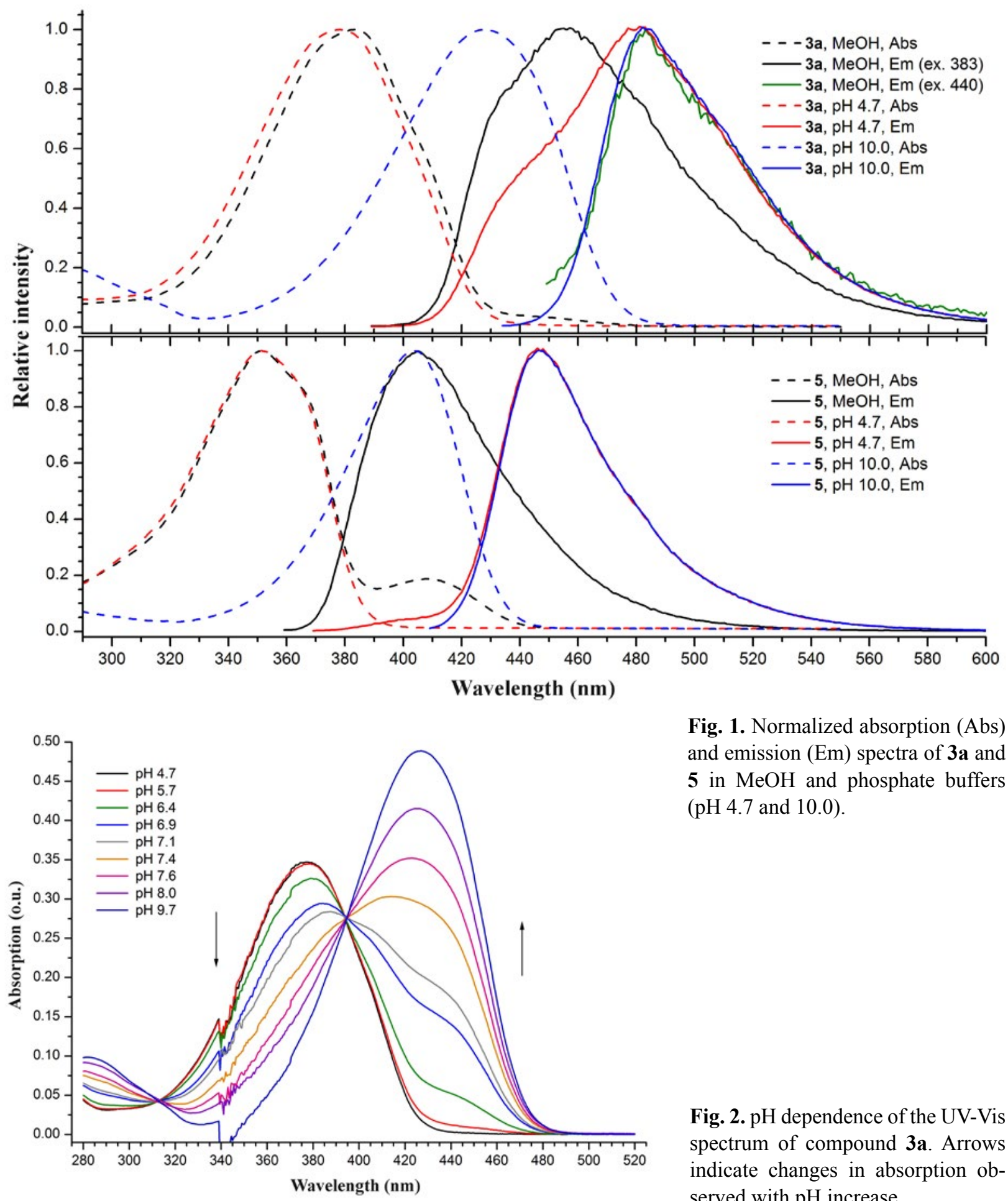

Fig. 1. Normalized absorption (Abs) and emission (Em) spectra of $\mathbf{3 a}$ and 5 in $\mathrm{MeOH}$ and phosphate buffers (pH 4.7 and 10.0).

Fig. 2. pH dependence of the UV-Vis spectrum of compound 3a. Arrows indicate changes in absorption observed with $\mathrm{pH}$ increase. 

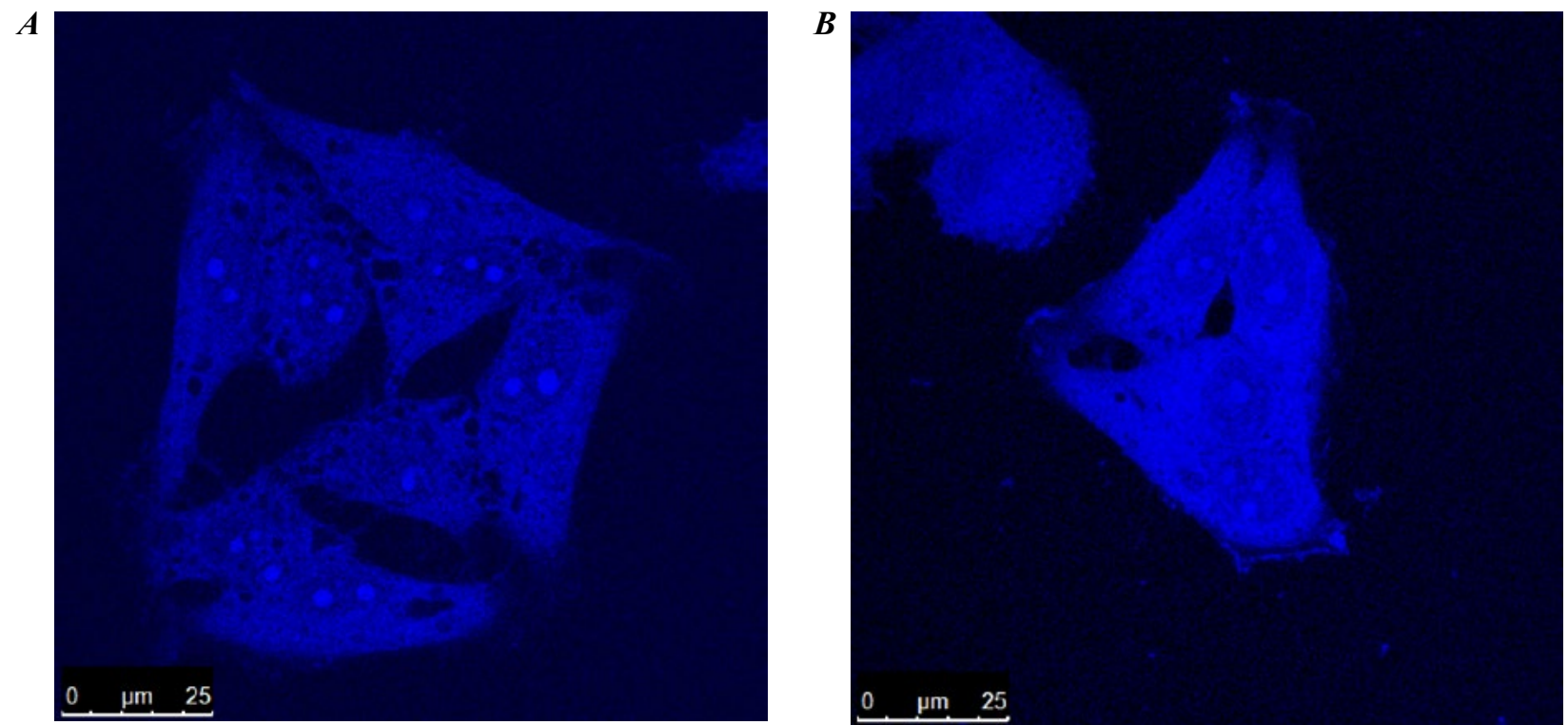

Fig. 3. Confocal microscopy images of HeLa cells stained with reagents $\mathbf{3 a}(\mathrm{A})$ and $\mathbf{3 b}(\mathrm{B})$.

standard cell washing $(3 \times$ with 5 min incubation) resulted in a dramatic decrease of fluorescence intensity. Perhaps the staining protocol is not yet optimized.

Confocal microscopy shows that the blueemitting reagents $\mathbf{3} \mathbf{a}$ and $\mathbf{3 b}$ penetrate the cell membrane and predominantly localize in the cytoplasm and nucleolus. We believe that this happens via the GLUTs; however, the staining in the presence of GLUT inhibitors was not performed.

In the experiments with 5 we have observed weak fluorescence with a fast decrease in intensity (data not shown). Thus, the presence of thiazole ring linked to the coumarin core at the C-3 position and/or a linker group between the dye and sugar moieties improves the staining efficiency of the conjugates. The effect of these structural elements could possibly be due to increasing a distance between the conjugate fragments or an additional conformational flexibility provided to the probe.

Establishing the nature of the effect of emission decrease requires further research, but we suppose that it could be of a chemical origin. The processes like photobleaching, coumarin ring opening or fast metabolism in the cell could result in a loss of the conjugate fluorescence.

\section{Conclusions}

New conjugates of D-glucosamine with blueemitting 3-thiazolylcoumarins were obtained by the active ester approach. They exist as mixtures of $\alpha$ - and $\beta$-anomers where $\alpha$-anomers are the major components. These compounds, especially 7-hydroxycoumarin conjugates, have good water solubility. The spectral properties of 7-hydroxycoumarin derivatives are $\mathrm{pH}$-sensitive. The conjugates have high quantum yields and large Stokes shifts. Thus, 3-thiazolylcoumarins are efficient glycosyl labels. 
We have demonstrated the uptake of compounds $\mathbf{3 a , b}$ by HeLa cells allowing their use as the cell imaging agents.

\section{Acknowledgments}

We thank Olga Iungin (IMBG) for assistance with confocal microscopy experiments.

\section{REFERENCES}

1. Tuomi T, Santoro N, Caprio S, Cai M, Weng J, Groop $L$. The many faces of diabetes: a disease with increasing heterogeneity. Lancet. 2014; 383(9922): 1084-94.

2. Hay N. Reprogramming glucose metabolism in cancer: can it be exploited for cancer therapy? Nat Rev Cancer. 2016; 16(10): 635-49.

3. Łojko D, Owecki M, Suwalska A. Impaired glucose metabolism in bipolar patients: The role of psychiatrists in its detection and management. Int $J$ Environ Res Public Health. 2019; 16(7): 1132.

4. Vallabhajosula S, Solnes L, Vallabhajosula B. A broad overview of positron emission tomography radiopharmaceuticals and clinical applications: What is new? Semin Nucl Med. 2011; 41(4): 246-64.

5. Momcilovic $M$, Shackelford $D B$. Imaging cancer metabolism. Biomol Ther. 2018; 26(1): 81-92.

6. Hu F, Chen Z, Zhang L, Shen Y, Wei L, Min W. Vibrational imaging of glucose uptake activity in live cells and tissues by stimulated Raman scattering. Angew Chem Int Ed. 2015; 54(34): 9821-5.

7. Maric T, Mikhaylov G, Khodakivskyi P, Bazhin A, Sinisi R, Bonhoure N, Yevtodiyenko A, Jones A, Muhunthan V, Abdelhady G, Shackelford D, Goun E. Bioluminescent-based imaging and quantification of glucose uptake in vivo. Nat Methods. 2019; 16(6): 526-32.

8. Terai T, Nagano T. Small-molecule fluorophores and fluorescent probes for bioimaging. Pflugers Arch Eur J Physiol. 2013; 465: 347-59.

9. Jun JV, Chenoweth DM, Petersson EJ. Rational design of small molecule fluorescent probes for biological applications. Org. Biomol. Chem. 2020; 18(30): 5747-63.
10. Thomas B, Yan $K-C$, Hu $X-L$, Donnier-Maréchal $M$, $C h e n$ G- $R$, He $X-P$, Vidal $S$. Fluorescent glycoconjugates and their applications. Chem Soc Rev. 2020; 49(2): 593-641.

11. Speizer L, Haugland R, Kutchai H. Asymmetric transport of a fluorescent glucose analogue by human erythrocytes. Biochim Biophys Acta Biomembr. 1985; 815(1): 75-84.

12. Yoshioka K, Takahashi H, Homma T, Saito M, Oh $K B$, Nemoto $Y$, Matsuoka $H$. A novel fluorescent derivative of glucose applicable to the assessment of glucose uptake activity of Escherichia coli. Biochim Biophys Acta Gen Subj. 1996; 1289(1): 5-9.

13. Yamada K, Saito M, Matsuoka H, Inagaki N. A realtime method of imaging glucose uptake in single, living mammalian cells. Nat Protoc. 2007; 2(3): 753-62.

14. Jung DW, Ha HH, Zheng X, Chang YT, Williams $D R$. Novel use of fluorescent glucose analogues to identify a new class of triazine-based insulin mimetics possessing useful secondary effects. Mol Biosyst. 2011; 7(2): 346-58.

15. Jo A, Park J, Park SB. Exploiting the mechanism of cellular glucose uptake to develop an imagebased high-throughput screening system in living cells. Chem Commun. 2013; 49(45): 5138-40.

16. Schmidtl S, Iancu CV, Choe J, Oreb M. Ligand screening systems for human glucose transporters as tools in drug discovery. Front Chem. 2018; 6: 183.

17. Cheng Y, Shabir G, Li X, Fang L, Xu L, Zhang H, $\mathrm{Li} E$. Development of a deep-red fluorescent glucose-conjugated bioprobe for in vivo tumor targeting. Chem Commun. 2020; 56(7): 1070-3.

18. Chen $S$, Fang $Y$, Zhu $Q$, Zhang $W$, Zhang $X, L u W$. NIR fluorescent DCPO glucose analogues and their application in cancer cell imaging. RSC Adv. 2016; 6(85): 81894-901.

19. Agrawalla BK, Lee HW, Phue WH, Raju A, Kim JJ, Kim HM, Kang NY, Chang YT. Two-photon dye cocktail for dual-color 3D imaging of pancreatic beta and alpha cells in live islets. $J$ Am Chem Soc. 2017; 139(9): 3480-7.

20. Zhang M, Zhang Z, Blessington D, Li H, Busch TM, Madrak V, Miles J, Chance B, Glickson JD, 
Zheng G. Pyropheophorbide 2-deoxyglucosamide: a new photosensitizer targeting glucose transporters. Bioconjug Chem. 2003; 14(4): 709-14.

21. Cheng Z, Levi J, Xiong Z, Gheysens O, Keren S, Chen X, Gambhir SS. Near-infrared fluorescent deoxyglucose analogue for tumor optical imaging in cell culture and living mice. Bioconjug Chem. 2006; 17(3): 662-9.

22. Ye Y, Bloch S, Kao J, Achilefu S. Multivalent carbocyanine molecular probes: Synthesis and applications. Bioconjug Chem. 2005; 16(1): 51-61.

23. Law WHT, Lee LCC, Louie MW, Liu HW, Ang TWH, Lo KKW. Phosphorescent cellular probes and uptake indicators derived from cyclometalated iridium(III) bipyridine complexes appended with a glucose or galactose entity. Inorg Chem. 2013; 52(22): 13029-41.

24. Yamada K, Onoe H, Teshima T, Yamamoto T. Method for imaging cell using fluorescence-labeled sugar derivative having coumarin derivative bound thereto, and imaging agent. Patent US10288604, May 14, 2019.

25. Wu Q, Cai M, Gao J, Zhao T, Xu H, Yan Q, Jing Y, Shi Y, Kang C, Liu Y, Liang F, Chen J, Wang $H$. Developing substrate-based small molecule fluorescent probes for super-resolution fluorescent imaging of various membrane transporters. Nanoscale Horizons. 2020; 5(3): 523-9.

26. Jo A, Sung J, Lee S, Nam H, Lee HW, Park J, Kim HM, Kim E, Park SB. Near-IR fluorescent tracer for glucose-uptake monitoring in live cells. Bioconjug Chem. 2018; 29(10): 3394-401.

27. Katritzky AR, Cusido J, Narindoshvili T. Monosaccharide-based water-soluble fluorescent tags. Bioconjug Chem. 2008; 19(7): 1471-5.

28. Hong JY, Price IR, Bai JJ, Lin H. A Glycoconjugated SIRT2 inhibitor with aqueous solubility allows structure-based design of SIRT2 inhibitors. ACS Chem Biol. 2019; 14(8): 1802-10.

29. Cao J, Cui S, Li S, Du C, Tian J, Wan S, Qian Z, Gu Y, Chen WR, Wang $G$. Targeted cancer therapy with a 2-deoxyglucose-based adriamycin complex. Cancer Res. 2013; 73(4): 1362-73.

30. Augustin $R$. The protein family of glucose transport facilitators: it's not only about glucose after all. IUBMB Life. 2010; 62(5): 315-33.
31. Tanasova M, Fedie JR. Molecular tools for facilitative carbohydrate transporters (Gluts). ChemBioChem. 2017; 18(18): 1774-88.

32. Park J, Um JI, Jo A, Lee J, Jung DW, Williams DR, Park $S B$. Impact of molecular charge on GLUTspecific cellular uptake of glucose bioprobes and in vivo application of the glucose bioprobe, GB2-Cy3. Chem Commun. 2014; 50(66): 9251-4.

33. Kuziv IaB, Ishchenko VV, Khilya VP, Dubey IYa. Synthesis of reagents based on 7-substituted 3-thiazolylcoumarins for covalent labeling of oligonucleotides. Ukr Bioorg Acta. 2008; 6(1): 3-12.

34. Kuziv IaB, Ishchenko VV, Khilya VP, Dubey IYa. Synthesis of carboxyalkyl derivatives of 3-furylcoumarins for the fluorescent labeling of biomolecules. Ukr Bioorg Acta. 2009; 7(2): 47-54.

35. Kuziv I, Dubey L, Dubey I. Synthesis, spectral properties and evaluation of carboxy-functionalized 3-thiazolylcoumarins as blue-emitting fluorescent labeling reagents. Tetrahedron Lett. 2020; 61(35): 152227.

36. Salgado LEV, Vargas-Hernández C. Spectrophotometric determination of the $\mathrm{pK}_{\mathrm{a}}$, isosbestic point and equation of absorbance vs $\mathrm{pH}$ for a universal pH indicator. Am J Anal Chem. 2014; 05(17): 1290301.

37. Kuziv IaB, Dubey IYa. Direct labeling of nucleosides with 3-thiazolylcoumarin fluorescent dyes. Biopolym Cell. 2020; 36(1): 36-47.

38. Bartnik M, Facey PC. Glycosides. In Badal McCreath S., Delgoda R. (Eds.). Pharmacognosy: Fundamentals, Applications and Strategy, Academic Press: London-San Diego, 2017, p. 101-61.

39. Patra M, Awuah SG, Lippard SJ. Chemical approach to positional isomers of glucose-platinum conjugates reveals specific cancer targeting through glucosetransporter-mediated uptake in vitro and in vivo. J Am Chem Soc. 2016; 138(38): 12541-51.

40. Glenister A, Simone MI, Hambley TW. A Warburg effect targeting vector designed to increase the uptake of compounds by cancer cells demonstrates glucose and hypoxia dependent uptake. PLoS One. 2019; 14(7): 0217712.

41. Liu FC, Su CR, Wu TY, Su SG, Yang HL, Lin JHY, $W u T S$. Efficient ${ }^{1} \mathrm{H}-\mathrm{NMR}$ quantitation and investi- 
gation of N-acetyl-D-glucosamine (GlcNAc) and $\mathrm{N}, \mathrm{N}$ '-diacetylchitobiose (GlcNAc) $)_{2}$ from chitin. Int J Mol Sci. 2011; 12(9): 5828-5843.

42. Breitmaier E. Structure Elucidation by NMR in Organic Chemistry: a Practical Guide, $3^{\text {rd }}$ Ed., John Wiley \& Sons, Chichester, UK, 2002, p. 11-68.

43. Fink DW, Koehler WR. pH effects on fluorescence of umbelliferone. Anal Chem. 1970; 42(9): 990-3.

44. Wolfbeis OS. pH-dependent fluorescence spectra of 3-substituted umbelliferones. Zeitschrift für Naturforsch. A 1977; 32a: 1065-7.

45. De Silva N, Minezawa N, Gordon MS. Excited-state hydrogen atom transfer reaction in solvated 7-hydroxy-4-methylcoumarin. J Phys Chem B. 2013; 117(49): 15386-94.

46. Hamilton KE, Rekman JF, Gunnink LK, Busscher BM, Scott JL, Tidball AM, Stehouwer NR, Johnecheck GN, Looyenga BD, Louters LL. Quercetin inhibits glucose transport by binding to an exofacial site on GLUT1. Biochimie. 2018; 151: 107-14.

\section{Флуоресцентні кон'югати D-глюкозаміну} з 3-тіазолілкумаринами: синтез, характеризація та потенційне застосування як реагентів для візуалізації клітин

Я. Б. Кузів, О. В. Новосильна. І. Я. Дубей

Мета. Синтез і вивчення кон'югатів глюкозамін-кумарин як можливих реагентів для флуоресцентної візуалізації клітин. Методи. Органічний синтез, ЯМР, оптична спектроскопія, конфокальна мікроскопія. Результати. Кон'югати D-глюкозаміну з 7-заміщеними 3-тіазолілкумаринами отримано з виходами 55-82 \% реакцією NHS-активованих естерів карбокси-модифікованих барвників з аміногрупою цукру. За допомогою ЯМР визначено аномерну конфігурацію продуктів.
Досліджено їхні спектрільні властивості в метанолі й фосфатному буфері. Попередньо оцінено можливість використання кон'югатів для фарбування клітин. Висновки. Тіазолілкумарин-мічені глюкозаміни 3 яскравою блакитною емісією - перспективні реагенти для візуалізації клітин.

К л ю ч о в і с л о в а: кумарини, глюкозамін, кон'югати, флуоресценція, конфокальна мікроскопія

\section{Флуоресцентные конъюгаты D-глюкозамина с 3-тиазолилкумаринами: синтез, характеризация и потенциальное использование как реагентов для визуализации клеток}

Я. Б. Кузив, А. В. Новосильная. И. Я. Дубей

Цель. Синтез и исследование конъюгатов глюкозамин-кумарин как возможных реагентов для флуоресцентной визуализации клеток. Методы. Органический синтез, ЯМР, оптическая спектроскопия, конфокальная микроскопия. Результаты. Конъюгаты D-глюкозамина с 7-замамещенными 3-тиазолилкумаринами получены с выходами 55-82 \% реакцией NHS-активированных эфиров карбокси-модифицированных красителей с аминогруппой сахара. При помощи ЯМР определена аномерная конфигурация продуктов. Исследованы их спектральные свойства в метаноле и фосфатном буфере. Предварительно оценена возможность применения конъюгатов для окрашивания клеток. Выводы. Тиазолилкумарин-меченые глюкозамины с яркой голубой эмиссией - перспективные реагенты для визуализации клеток.

К л ю ч е в ы е с л о в а: кумарины, глюкозамин, конъюгаты, флуоресценция, конфокальная микроскопия

Received 15.08.2020 